University of Nebraska - Lincoln

DigitalCommons@University of Nebraska - Lincoln

\title{
Comparison of Field-Scale Herbicide Runoff and Volatilization Losses: An Eight-Year Field Investigation
}

Timothy J. Gish

USDA-ARS, timothy.gish@ars.usda.gov

John H. Prueger

USDA-ARS

Craig S. T. Daughtry

USDA-ARS

William P. Kustas

USDA-ARS

Lynn G. McKee

USDA-ARS

See next page for additional authors

Follow this and additional works at: https://digitalcommons.unl.edu/usdaarsfacpub

Gish, Timothy J.; Prueger, John H.; Daughtry, Craig S. T.; Kustas, William P.; McKee, Lynn G.; Russ, Andrew L.; and Hatfield, Jerry L., "Comparison of Field-Scale Herbicide Runoff and Volatilization Losses: An EightYear Field Investigation" (2011). Publications from USDA-ARS / UNL Faculty. 1367.

https://digitalcommons.unl.edu/usdaarsfacpub/1367

This Article is brought to you for free and open access by the U.S. Department of Agriculture: Agricultural Research Service, Lincoln, Nebraska at DigitalCommons@University of Nebraska - Lincoln. It has been accepted for inclusion in Publications from USDA-ARS / UNL Faculty by an authorized administrator of DigitalCommons@University of Nebraska - Lincoln. 


\section{Authors}

Timothy J. Gish, John H. Prueger, Craig S. T. Daughtry, William P. Kustas, Lynn G. McKee, Andrew L. Russ, and Jerry L. Hatfield 


\title{
Comparison of Field-scale Herbicide Runoff and Volatilization Losses: An Eight-Year Field Investigation
}

\author{
Timothy J. Gish, * John H. Prueger, Craig S.T. Daughtry, William P. Kustas, Lynn G. McKee, Andrew L. Russ, and Jerry L. Hatfield
}

An 8-yr study was conducted to better understand factors influencing year-to-year variability in field-scale herbicide volatilization and surface runoff losses. The 21-ha research site is located at the USDA-ARS Beltsville Agricultural Research Center in Beltsville, MD. Site location, herbicide formulations, and agricultural management practices remained unchanged throughout the duration of the study. Metolachlor [2-chloro- $N$-(2-ethyl-6-methylphenyl)- $N$-(2-methoxy-1methylethyl) acetamide] and atrazine [6-chloro- $N$-ethyl- $N^{\prime}-(1-$ methylethyl)-1,3,5-triazine-2,4-diamine] were coapplied as a surface broadcast spray. Herbicide runoff was monitored from a month before application through harvest. A flux gradient technique was used to compute volatilization fluxes for the first $5 \mathrm{~d}$ after application using herbicide concentration profiles and turbulent fluxes of heat and water vapor as determined from eddy covariance measurements. Results demonstrated that volatilization losses for these two herbicides were significantly greater than runoff losses $(P<0.007)$, even though both have relatively low vapor pressures. The largest annual runoff loss for metolachlor never exceeded $2.5 \%$, whereas atrazine runoff never exceeded $3 \%$ of that applied. On the other hand, herbicide cumulative volatilization losses after $5 \mathrm{~d}$ ranged from about 5 to $63 \%$ of that applied for metolachlor and about 2 to $12 \%$ of that applied for atrazine. Additionally, daytime herbicide volatilization losses were significantly greater than nighttime vapor losses $(P<0.05)$. This research confirmed that vapor losses for some commonly used herbicides frequently exceeds runoff losses and herbicide vapor losses on the same site and with the same management practices can vary significantly year to year depending on local environmental conditions.
Copyright $\odot 2011$ by the American Society of Agronomy, Crop Science Society of America, and Soil Science Society of America. All rights reserved. No part of this periodical may be reproduced or transmitted in any form or by any means, electronic or mechanical, including photocopying, recording, or any information storage and retrieval system, without permission in writing from the publisher.

J. Environ. Qual. 40:1432-1442 (2011)

doi:10.2134/jeq2010.0092

Published online 14 Sept. 2010.

Received 4 Mar. 2010.

*Corresponding author (timothy.gish@ars.usda.gov).

(c) ASA, CSSA, SSSA

5585 Guilford Rd., Madison, WI 53711 USA
$\mathrm{H}$ ERBICIDES PLAY AN IMPORTANT ROLE in maintaining worldwide food and fiber production by controlling weeds that compete for water and nutrients. Although the use of pesticides in the United States has increased from 38 million $\mathrm{kg}$ of active ingredient in 1964 to 221 million $\mathrm{kg}$ of active ingredient in 1979, the total mass of herbicide used in the United States has remained steady since 1979 (Aspelin, 1994; USGS, 2002). Atrazine and metolachlor are two of the most widely used herbicides in agriculture with more than 30 million $\mathrm{kg}$ (a.i.) of metolachlor and 33 million $\mathrm{kg}$ (a.i.) of atrazine being applied to U.S. crops in 2002 alone (USGS, 2002). The USEPA (2008) classified both atrazine and metolachlor as nonvolatile and identified their major off-site transport mechanism as surface runoff. However, field monitoring of herbicide fluxes from all possible off-site loss pathways is essentially nonexistent. Environmental monitoring of herbicides is complex because they are not chemically conservative and can be adsorbed to soil particles and/or exist in the liquid and vapor phases (Majewski and Capel, 1995). The distribution of a pesticide among the sorbed, liquid, and gaseous states is a function of its physiochemical properties, the soil's biological/physiochemical properties, and climatic variables, which, in turn, govern the pesticide's environmental dispersal (Symons, 1977; Jury et al., 1983; Taylor and Spencer, 1990; Tsal and Cohen, 1991; Majewski and Capel, 1995; Cousins et al., 1999; Prueger et al., 2005; Gish et al., 2009). To maintain productive and sustainable agricultural systems, there is a need to understand field-scale processes governing herbicide use and off-site movement.

Herbicide field studies where all off-site transport mechanisms are monitored are rare, although specific aspects of pesticide movement have been rigorously studied. The three major off-site transport mechanisms for herbicides are surface runoff, leaching, and volatilization into the atmosphere. Among these transport mechanisms, herbicide runoff has been the most intensively studied and is generally $<3 \%$ of that applied (Wauchope, 1978; Baker, 1980; Hall et al., 1983; Felsot et al., 1990; Haith and

\footnotetext{
Timothy J. Gish, USDA-ARS Hydrology and Remote Sensing Laboratory, Beltsville, MD; John H. Prueger, USDA-ARS National Laboratory for Agriculture and the Environment, Ames, IA; Craig S.T. Daughtry, Hydrology and Remote Sensing Laboratory, Beltsville, MD; William P. Kustas, USDA-ARS Hydrology and Remote Sensing Laboratory, Beltsville, MD; Lynn G. McKee, USDA-ARS Hydrology and Remote Sensing Laboratory, Beltsville, MD; Andrew Russ, Hydrology and Remote Sensing Laboratory, Beltsville, MD; and Jerry L. Hatfield, USDA-ARS National Laboratory for Agriculture and the Environment, Ames, IA. Trade names are for the benefit of the reader and imply no endorsement by USDA. Assigned to Associate Editor Sharon Papiernik.
}

Abbreviations: EST, Eastern Standard Time; OPE3, Optimizing Production Inputs for Economic and Environmental Enhancement site; PUF, polyurethane foam. 
Rossi, 2003; Domagalski et al., 2008). Herbicide leaching has also been intensively studied, but tile drain studies suggest that that herbicide runoff is more detrimental to the environment than herbicide leaching (LaFleur et al., 1975; Muir and Baker, 1976; Ng et al., 1995). Unfortunately, field-scale pesticide leaching losses in non-tile-drained fields is difficult to quantify since heterogeneity and preferential flow creates uncertainty in flux estimates (Koplin et al., 1998; Jarvis, 2002; Elliott et al., 2000; Malone et al., 2004a; Malone et al., 2004b; Kodesova et al., 2008). Of the three major off-site transport mechanisms, herbicide volatilization is studied the least, even though typical losses from crop production fields range from 2 to $25 \%$ of that applied (Grover et al., 1988; Glotfelty and Schomburg 1989; Wienhold and Gish, 1994; Prueger et al., 1999; Rice et al., 2002; Prueger et al., 2005). Once in the atmosphere, herbicides can be degraded or deposited in nontargeted areas via wet or dry deposition (Bidleman and Christensen, 1979; Bidleman, 1988; Burrows et al., 2002). Frequently, a portion of the applied herbicide that has volatilized into the atmosphere is transported and subsequently deposited in streams, rivers, and lakes (McConnell et al., 1998; Alegria and Shaw, 1999; Thurman and Cromwell, 2000; Kuang et al., 2003). As a result, there is a need to simultaneously quantify herbicide losses from the major off-site transport pathways at the field scale so environmental risks can be more accurately formulated.

Herbicide surface runoff is a concern in many watersheds because intensive agriculture may be adjacent to sensitive ecosystems (Capel et al., 2008). Typical runoff losses for most herbicides are $<1$ to $2 \%$ of that applied (Wauchope, 1978; Baker, 1980). In rare situations, such as when a major rainfall event follows the application of a wettable powder formulation on a sloped field, as much as $15 \%$ of the pesticide applied can be lost through runoff (Baker, 1980; Haith and Rossi, 2003). Additionally, the herbicide application rate, water solubility, formulation, management practices, and landscape features are also important factors influencing herbicide runoff (Caro, 1976; Wauchope, 1978; Hall et al., 1983; Felsot et al., 1990; Domagalski et al., 2008). Regardless of the pesticide mass lost from runoff, detrimental impacts decrease with increasing distance from the application site due to dilution from other runoff sites, streams, rivers, and lakes.

Herbicide volatilization occurs in two steps-evaporation from soil and plant material, followed by dispersion into the atmosphere by diffusion and turbulent mixing (Taylor, 1995; Prueger et al., 2005). Because herbicide volatilization is complex, several methods have been developed to obtain estimates of pesticide volatilization at the field scale. Parmele et al. (1972) developed an aerodynamic method based on gradients of wind speed, temperature, and pesticide concentrations collected over a uniform area. Denmead et al. (1977) developed an integrated horizontal flux approach that uses pesticide concentration and horizontal wind speed profiles. For certain conditions, a theoretical profile shape method, which measures wind speed and pesticide concentration at a single height above the soil, may be useful (Wilson et al., 1982). Recently, wind, temperature, water, and herbicide profile data have been used to calculate eddy diffusivities of water, temperature, and momentum, which were subsequently used to calculate herbicide volatilization fluxes where turbulent flow conditions may exist (Prueger et al., 2005, Gish et al., 2009). The benefit of this latter approach is that atmospheric stability and nighttime pesticide vapor losses can be monitored.

The objective of this study was to conduct a long-term investigation where field-scale herbicide runoff and volatilization losses were simultaneously determined. This 8 -yr investigation: (i) lends insight into the relevance and variability of off-site transport mechanisms under variable field conditions, (ii) determines the impact of local field conditions on the offsite transport mechanisms, and (iii) determines the impact of daytime and nighttime conditions on herbicide volatilization.

\section{Materials and Method}

\section{Site Description and Pesticide Application}

The research site is a 21-ha agricultural production farm located at the USDA, Henry A. Wallace Beltsville Agricultural Research Center, in Beltsville, MD (near lat. 39 $01^{\prime} 44^{\prime \prime}$, long. $\left.76^{\circ} 50^{\prime} 46.1^{\prime \prime}\right)$. A variety of data, including general soil properties, crop parameters, and geophysical, meteorological, and remotely sensed data are acquired annually on this site, which is called Optimizing Production Inputs for Economic and Environmental Enhancement site (OPE3). One of the principal objectives of OPE 3 is to determine field- and catchmentscale fluxes of agricultural inputs. The site contains four fields, which range from 3.6 to 4.2 ha, each draining into a first-order stream and riparian wetland, and each delimited with earthen berms (Fig. 1). The soils are variable but sandy, with the majority being typic hapludults, coarse-loamy, siliceous, mesic. The surface soil textures range from sandy loam to loamy sand, have an average organic matter content of $<3 \%$, and are well drained. Additionally, the 7 ha surrounding the eddy covariance meteorological station (fields 1 and 2) is relatively flat with $80 \%$ of the surface having slopes $<2 \%$. Tillage, crop, residue management, and pesticide formulations and application rates are the same for the entire 21-ha research site.

\section{Surface and Energy Balance/ Meteorological Instrumentation}

Surface energy balance and eddy covariance instrumentation were mounted on a 10-m tower and used to measure net radiation, soil heat flux, and sensible and latent heat flux densities. Net radiation and soil heat flux were measured with a CNR-1 net radiometer (Kipp \& Zonen, Inc., Bohemia, NY) and 3 HFT-1 soil heat flux plates (Radiation Energy Balance Systems, Inc. Seattle, WA), respectively. The CNR-1 was positioned $4 \mathrm{~m}$ above the soil surface. Six soil heat flux plates were buried at 0.08 $\mathrm{m}$ below the soil surface, all within $3 \mathrm{~m}$ of the meteorological tower. Above each soil heat flux plate are two Type-T (copperconstantan) soil thermocouples buried at 0.02 and $0.06 \mathrm{~m}$. Soil temperature data were used to compute the storage component of the above-the-soil heat flux plates. A 3-D sonic anemometer (Campbell Scientific, Inc., Logan, UT) and L17500 infrared hygrometer (LICOR, Inc., Lincoln, NE) measured sensible and latent heat fluxes as the covariance of the vertical wind velocity with air temperature and water vapor density. Soil surface temperatures were monitored using precision infrared thermocouple sensors (Model IRTS-P, Apogee Instruments, Logan, 


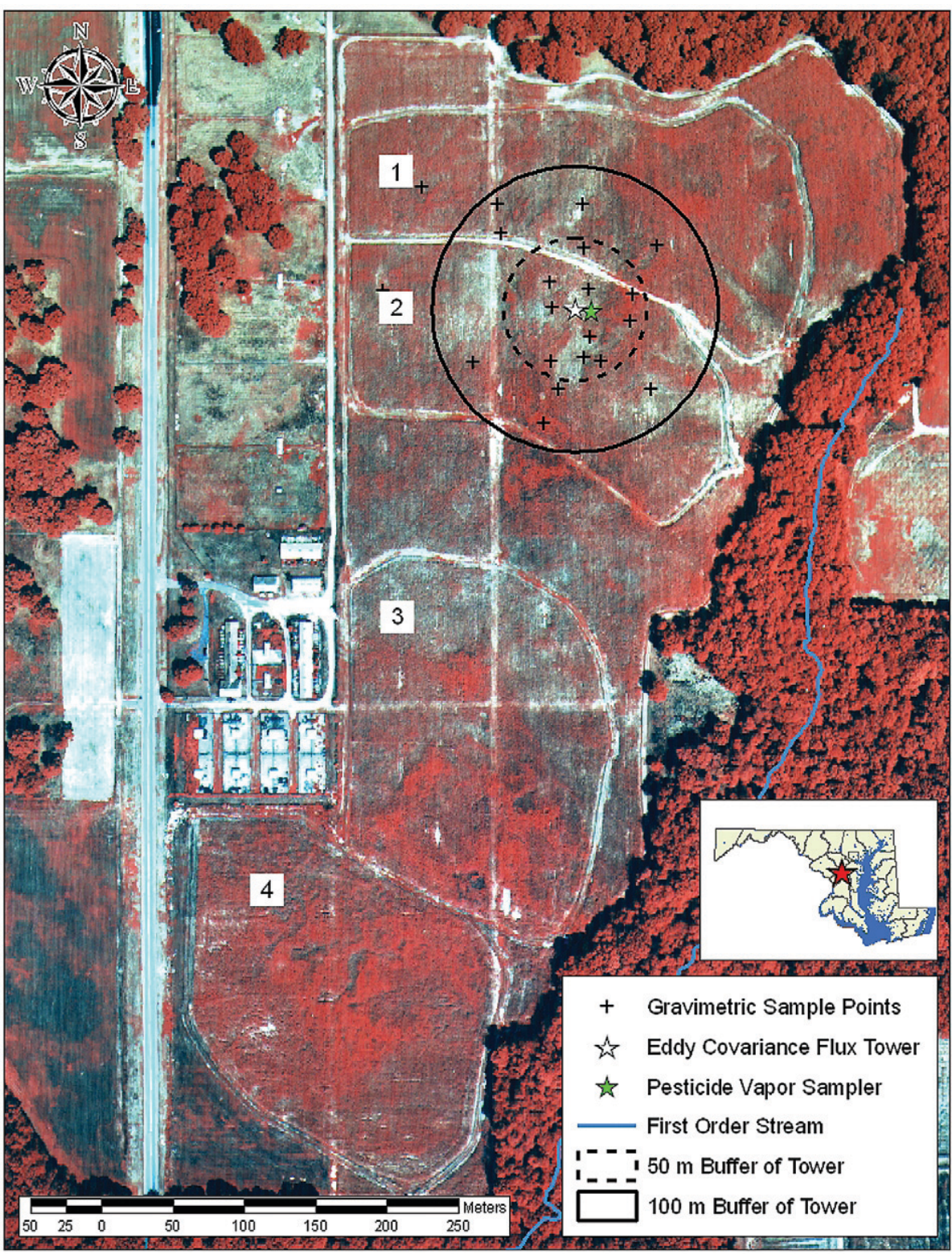

Fig. 1. Optimizing Production Inputs for Economic and Environmental Enhancement field site (OPE3), showing location of eddy covariance meteorological station and early morning soil sampling locations for a representative year. Numbers denote individual fields. The dotted circle represents a distance of $50 \mathrm{~m}$ from the eddy covariance meteorological station, whereas the solid circle represents a distance of $100 \mathrm{~m}$.

UT). Standard local surface meteorological instrumentation was mounted on the tower to measure mean wind speed and direction, relative humidity, and precipitation. Data from the standard meteorological instruments were stored as 30 -min averages. Additionally, the sampling frequency was $20 \mathrm{~Hz}$ for the eddy covariance and $10 \mathrm{~s}$ for the energy balance system.

\section{Herbicides Application and Detection}

Herbicides were coapplied as a surface broadcast spray onto a tilled, bare soil surface. Timing of planting and herbicide applications (Table 1) varied across years as a function of local precipitation patterns and technical and/or logistical problems that are typically encountered with any planting operation. With the exception of 2003, herbicides were applied within $2 \mathrm{~d}$ after the corn was planted. In 2003, the spring was unusually wet and planting was delayed until early July and herbicides were subse- quently applied a week later. In all cases, atrazine was applied at $1.13 \mathrm{~kg} \mathrm{ha}^{-1}$, whereas metolachlor was applied at 1.51 $\mathrm{kg} \mathrm{ha}^{-1}$ as $\mathrm{S}-$ metolachlor over the entire 21-ha site. Each year the herbicide mass applied was achieved by using two herbicide formulations (Table 2).

Surface runoff was monitored with a 46-cm H-flume, flow meter bubbler, and sampler (Isco, Lincoln, NE). Flumes were calibrated by collecting runoff volumes at various runoff rates and using these data to correct the factory calibration. Sampling frequency was based on water flow. One runoff sample was generally collected for every $1200 \mathrm{~L}$ of surface runoff and subsequently refrigerated at $5^{\circ} \mathrm{C}$ until they could be analyzed. Runoff samples were typically stored less than 24 $\mathrm{h}$ before being quantitatively analyzed. Observed herbicide runoff concentrations and surface water fluxes were combined to generate daily herbicide runoff fluxes. Surface runoff was monitored at least 1 mo before planting and pesticide application. Monitoring continued until harvest when runoff samplers were turned off due to freezing conditions.

The vapor flux gradient technique links atmospheric vertical profile concentrations of metolachlor and atrazine with a pesticide eddy diffusivity term computed from turbulent fluxes of momentum, heat, and water vapor to compute pesticide fluxes (Baldocchi et al., 1988; Verma, 1990). The metolachlor and atrazine volatilization fluxes are computed as the product of a mean vertical pesticide concentration gradient and a turbulent-transport coefficient. Using the flux gradient approach for pesticide flux estimates is based on extending the assumption that transport similarity exists for pesticide vapor as it does for scalar and mass properties of momentum, sensible heat, and water vapor. This is reasonable since only the vapor phase of the pesticide above the soil matrix is of interest here. A more detailed discussion of this approach is found in Taylor (1995) and Prueger et al. (2005).

Atrazine and metolachlor vapor sampling began approximately $30 \mathrm{~min}$ after application and continued every $2 \mathrm{~h}$ for the first $120 \mathrm{~h}(5 \mathrm{~d})$ after application. Each sampling mast had four glass canisters $(0.0254 \mathrm{~m}$ i.d. by $0.15 \mathrm{~m})$, each at a different height-0.3, 0.6, 1.2, and $1.95 \mathrm{~m}$ above the soil surface. The glass canisters were tapered at one end to a stem of $0.0085 \mathrm{~m}$ diameter and were connected with Tygon tubing to a high volume air vacuum pump (Model TFIA, Staplex, Inc., Brooklyn, NY) calibrated to a flow rate of approximately $50 \mathrm{~L}$ $\mathrm{min}^{-1}$ through each sampling canister. The individual canisters 
were also wrapped with aluminum reflective tape to prevent photodegradation of the samples. Each glass canister initially contained two polyurethane foam (PUF) plugs $(0.0254 \mathrm{~m}$ diam. by $0.075 \mathrm{~m}$ length) that were precleaned using separate ethyl acetate washes and allowed to air dry. After precleaning, 20 PUF plugs were randomly selected and analyzed as blanks. No interfering peaks were observed above our detection limits. In the canister, the first PUF plug served as the primary metolachlor and atrazine vapor trap, whereas the second inline PUF plug was analyzed to determine if any pesticide got past the primary PUF. Analysis of the second PUF supports Prueger et al. (2005) who found essentially no metolachlor on the second PUF $>24 \mathrm{~h}$ after herbicides had been applied. As a result, after $48 \mathrm{~h}$, each glass canister contained just one PUF plug. Airflow rates through the PUF canisters at each height were measured and recorded at the beginning and end of each sampling interval. After each sampling period, the PUF plugs were placed in glass containers, secured with Teflon-lined lids, and stored in a freezer at $-20^{\circ} \mathrm{C}$.

All soil water and air samples were quantitatively analyzed for atrazine and metolachlor using a Hewlett-Packard 5890 Series II (replaced with a 6890 in 2006) GC equipped with a nitrogenphosphorus detector. All PUF plugs were individually extracted with ethyl acetate for $4 \mathrm{~h}$ using a Soxhlet technique. Blank and fortification recovery controls were also included in sample extraction batches to determine extraction efficiency $(96 \% \pm 9$, $n=88$ ) and to detect contamination from laboratory procedures (all blanks were free of interfering peaks). Two sets of soil samples were collected at 4:30 a.m. Eastern Standard Time (EST), one for herbicide surface soil concentrations and the other for surface soil moisture. The soil surface samples were collected from 20 predetermined $1 \mathrm{~m}^{2}$ locations within fields (Fig. 1). Each soil can $(38.5$ $\mathrm{cm}^{2}$ area and $5 \mathrm{~cm}$ deep) used for herbicide analysis was refrigerated at $-20^{\circ} \mathrm{C}$ until samples could be analyzed (generally $<1 \mathrm{yr}$ ). After thawing, soil samples were extracted with 4:1 methanol/water. Then, the methanol was rotary evaporated. Runoff water samples were filtered through glass microfiber filters. Soil extracts and runoff water samples were then loaded onto prepared C18 Sep-Pak solid phase extraction cartridges (Waters Corporation, Milford, MA). Each C-18 cartridge was treated beforehand with $2 \mathrm{~mL}$ ethyl acetate, $2 \mathrm{~mL}$ methanol, and $10 \mathrm{~mL}$ deionized water. Herbicides in the soil and water extracts were eluded off the $\mathrm{C}-18$ cartridges with ethyl acetate to which trifluralin was added as an internal standard. Metabolites of atrazine and metolachlor were analyzed but are not reported because of their low concentrations and sporadic detection. The limit of detection for both herbicides was $5 \mathrm{ng} \mathrm{m}^{-3}$.

\section{Soil Moisture}

Surface soil moisture observations consisted of gravimetric samples $\left(38.5 \mathrm{~cm}^{2}\right.$ area and $5 \mathrm{~cm}$ deep) collected during pesticide application and subsequently at runoff was observed.
4:30 a.m. EST. These samples were taken within $150 \mathrm{~m}$ of the meteorological station and were used to monitor shallow soil water conditions that were most likely to be in equilibrium with the soil surface. A stratified random design was used each year to select the 20 sampling locations. Fifty percent of these soil moisture monitoring sites (10 locations) were randomly selected within $50 \mathrm{~m}$ of the eddy covariance meteorological station, whereas $40 \%$ of the sites (eight locations) were randomly selected from 50 to $100 \mathrm{~m}$ away, and finally $10 \%$ (two locations) were located $>100 \mathrm{~m}$ from the meteorological station but within the field boundaries. These soil water content observations were subsequently combined to determine an average soil moisture value.

\section{Results and Discussion Variability in Field Conditions}

The timing of precipitation events relative to herbicide application can dramatically influence both runoff and volatilization. As a result, all precipitation starting a week before herbicide application and $40 \mathrm{~d}$ after is shown in Fig. 2. Over the 8-yr period, there was a wide range in precipitation patterns. For example, rainfall occurred a few days before herbicide application for 2000 through 2004, whereas no meaningful precipitation occurred the week before application for 2005 through 2007. Additionally, during 2001 several rainfall events occurred shortly after application, whereas for other years, like 2007, no significant rainfall occurred within $25 \mathrm{~d}$ after herbicide application. Rainfall shortly before application increases the likelihood of enhanced herbicide volatilization and herbicide surface runoff (Goodrich et al., 1994; Gish et al., 2009). As a result, the precipitation patterns alone would suggest low herbicide volatilization losses and minimal surface runoff losses in years 2005 through

Table 1. Atrazine and metolachlor application dates and runoff losses.

\begin{tabular}{lcccc}
\hline \multirow{2}{*}{ Year } & $\begin{array}{c}\text { Application } \\
\text { date }\end{array}$ & $\begin{array}{c}\text { No. of } \\
\text { runoff eventst }\end{array}$ & \multicolumn{2}{c}{ Runoff losses (percentage of applied) } \\
\cline { 4 - 5 } 2000 & 13 June & 8 & Atrazine & Metolachlor \\
2001 & 20 June & 8 & 0.04 & 0.03 \\
2002 & 24 April & 9 & 2.94 & 2.45 \\
2003 & 14 July & 5 & $<0.01$ & $<0.01$ \\
2004 & 21 May & 3 & 0.91 & 0.42 \\
2005 & 10 May & 4 & $<0.01$ & $<0.01$ \\
2006 & 3 May & 4 & 0.18 & 0.11 \\
2007 & 8 May & $0 \neq$ & 0.06 & 0.06 \\
\hline
\end{tabular}

† No. of runoff events during the first 5 mo after herbicide application.

₹ Herbicide runoff was monitored for only the first month after application. During this time no

Table 2. Herbicide application rates and physiochemical characteristics. $\dagger$

\begin{tabular}{lcc}
\hline \multicolumn{1}{c}{ Herbicide characteristic } & Atrazine & Metolachlor \\
\hline Water solubility $\left(\right.$ at $\left.20^{\circ} \mathrm{C}\right)$ & $30 \mathrm{mg} \mathrm{L}^{-1}$ & $530 \mathrm{mg} \mathrm{L}^{-1}$ \\
Vapor pressure $\left(\right.$ at $\left.20^{\circ} \mathrm{C}\right)$ & $0.04 \mathrm{mPa}$ & $1.7 \mathrm{mPa}$ \\
Soil half-life & 60 to $100 \mathrm{~d}$ & 15 to $70 \mathrm{~d}$ \\
Mobility & Moderately mobile & Moderately mobile \\
Formulations & \multicolumn{2}{c}{ Dual II Magnum } \\
Application rate & $1.13 \mathrm{~kg} \mathrm{ha}^{-1}$ & $1.51 \mathrm{~kg} \mathrm{ha}^{-1}$ \\
\hline
\end{tabular}

† Gianessi and Marcelli (2000) and USEPA (2008). 

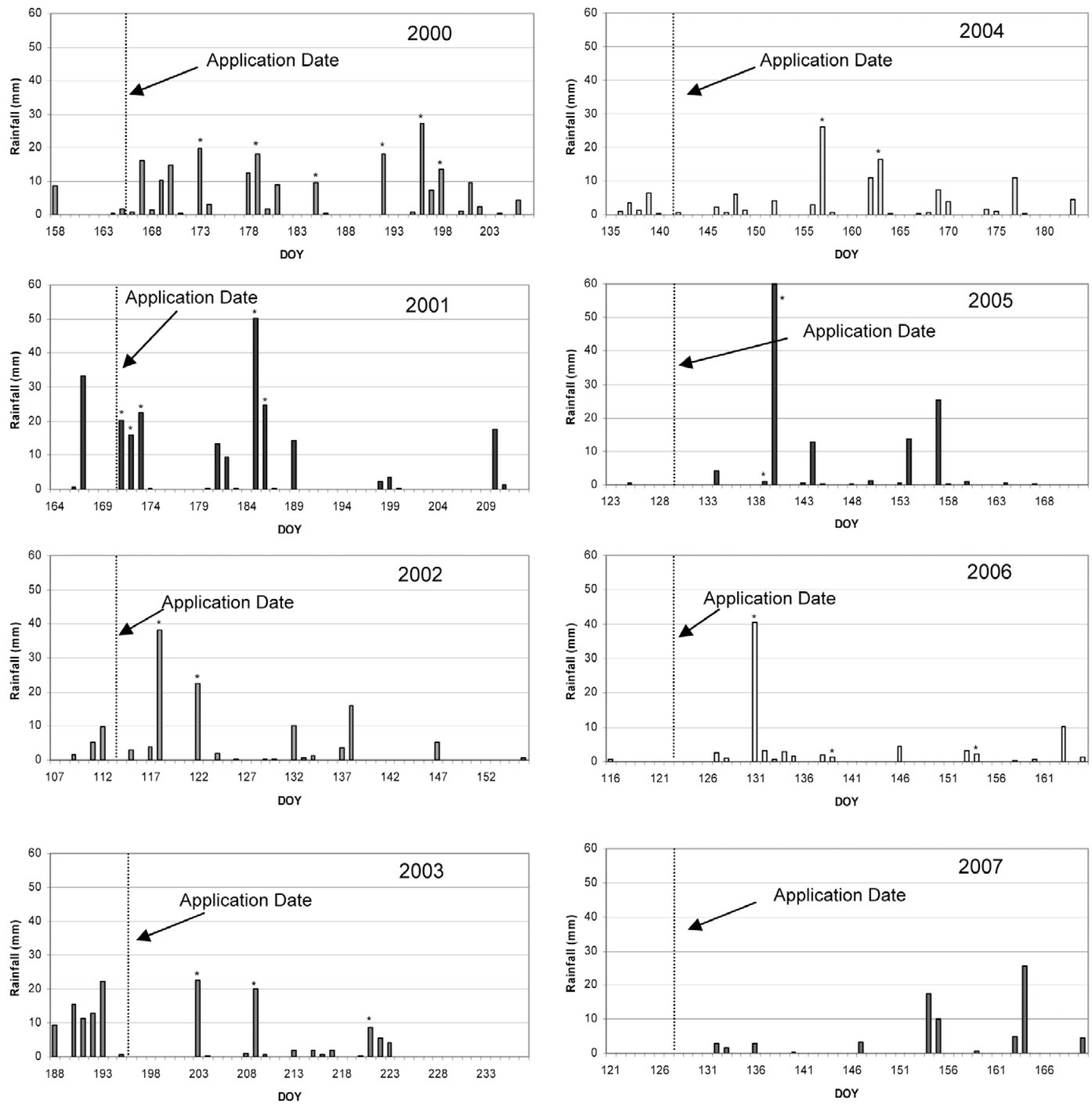

Fig. 2. Precipitation $1 \mathrm{wk}$ before and $40 \mathrm{~d}$ after pesticide application. Asterisks denote precipitation events that generated surface runoff.

2007. On the other hand, with rain occurring on 5 of the $7 \mathrm{~d}$ before application in 2003, the moist soils would tend to favor enhanced herbicide volatilization (Prueger et al., 2005).

Surface soil moisture at the time of application is critical to herbicide volatilization since moisture influences herbicide volatilization flux rates (Prueger et al., 2005; Gish et al., 2009). Daily surface gravimetric soil water contents for the top $5 \mathrm{~cm}$ are shown in Table 3. Soil moisture at the time herbicides were applied, $T_{0}$, were highest for 2003, followed by 2001 and 2004. On the other hand, $T_{\mathrm{o}}$ surface soil water contents were the lowest for years 2006 and 2007. The years 2000, 2002, and 2005 had intermediate surface soil moisture values relative to the other 5 yr. Although $\mathrm{T}_{\mathrm{o}}$ of 2003 was the wettest, no signifi- cant rain fell that year until the volatilization study was terminated. In 2001, it rained the evening herbicides were applied and each night thereafter for two additional nights. During 2004, there was a slight rain event the evening after application, but it did not rain again until the volatilization study was terminated. During 2006 and 2007, no rain fell until $5 \mathrm{~d}$ after herbicide application. As a result, during the 8-yr study a wide range of surface moisture conditions were encountered.

The 2003 growing season was atypical and will generally be discussed separately from the other 7 yr. During 2003, it rained several times each week from mid-April through early July, which delayed planting and pesticide applications. Since the corn had been planted a week earlier, herbicides had to 


\begin{tabular}{|c|c|c|c|c|c|c|}
\hline \multirow{3}{*}{ Year } & \multicolumn{6}{|c|}{ Gravimetric soil water content (SD) } \\
\hline & \multicolumn{6}{|c|}{ Hours after herbicide application } \\
\hline & $\mathrm{T}_{\mathrm{o}}$ & $\approx 20$ & $\approx 44$ & $\approx 68$ & $\approx 92$ & $\approx 116$ \\
\hline & \multicolumn{6}{|c|}{ 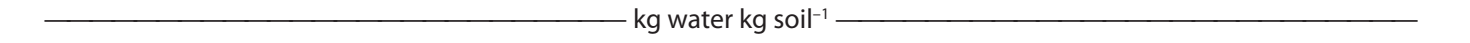 } \\
\hline 2000 & $0.16(0.02)$ & $0.15(0.03)$ & $0.15(0.02)$ & $0.23(0.03)$ & $0.19(0.03)$ & $0.22(0.03)$ \\
\hline 2001 & $0.19(0.06)$ & $0.24(0.03)$ & $0.25(0.05)$ & $0.27(0.07)$ & $0.24(0.06)$ & $0.21(0.05)$ \\
\hline 2002 & $0.15(0.02)$ & NS‡ & $0.15(0.02)$ & $0.13(0.02)$ & NS & $0.21(0.04)$ \\
\hline 2003 & $0.23(0.07)$ & $0.21(0.07)$ & $0.19(0.07)$ & $0.18(0.07)$ & $0.17(0.07)$ & $0.18(0.08)$ \\
\hline 2004 & $0.18(0.03)$ & $0.18(0.04)$ & $0.15(0.03)$ & $0.14(0.04)$ & $0.13(0.04)$ & $0.17(0.03)$ \\
\hline 2005 & $0.13(0.04)$ & $0.13(0.04)$ & $0.13(0.04)$ & $0.12(0.05)$ & $0.14(0.05)$ & $0.19(0.03)$ \\
\hline 2006 & $0.11(0.02)$ & $0.10(0.03)$ & $0.10(0.03)$ & $0.10(0.03)$ & $0.09(0.03)$ & $0.14(0.02)$ \\
\hline 2007 & $0.08(0.04)$ & $0.07(0.04)$ & $0.07(0.04)$ & $0.06(0.04)$ & $0.06(0.05)$ & $0.15(0.03)$ \\
\hline
\end{tabular}

† Gravimetric surface soil water contents collected at time of herbicide application and subsequently every day at 4:30 a.m. (Eastern Standard Time). ₹ No soil moisture samples taken due to poor weather conditions (thunderstorms).

be sprayed to kill emerging weeds before the corn grew much higher. This delay in herbicide application was not a typical agronomic practice but was due to the frequent rainfalls. At the time herbicides were applied in 2003, parts of the OPE3 field site (located $>100 \mathrm{~m}$ from the flux towers) were saturated (ponded). Much of the remaining surface area at the time of herbicide application was near saturation, which made obtaining accurate gravimetric samples with cans nearly impossible. Air trapped in the soil sampling cans (when inverted) would likely force some of the water out of the soil so that at least the $T_{0}$ soil water contents in 2003 are underestimated. The likelihood of some soil water sampling loss in 2003 is supported by surface water contents observed in 2001 (after $\mathrm{T}_{\mathrm{o}}$ ). During 2001, the second through fourth days after application showed higher soil water contents than during $T_{\circ}$ of 2003 , even though no saturated conditions were observed anywhere on site during 2001. As a result, 2003 may represent a worst-case scenario for herbicide vapor behavior as soils were near saturation and the delayed planting resulted in spraying when energy inputs and temperatures were high.

\section{Herbicide Runoff}

Herbicide losses through runoff are thought to be the greatest off-site transport mechanism for atrazine and metolachlor because both are moderately mobile, moderately persistent, and have low vapor pressures (Lyman et al., 1990; Gianessi and Marcelli, 2000; USEPA, 2008). Herbicide concentrations in the surface runoff over the 8-yr period are shown in Fig. 3. Maximum runoff concentrations for both herbicides occurred in 2001, when runoff occurred within the first day after application and then decreased exponentially with time. For years 2002, 2004, and 2007, the maximum runoff concentration never exceeded $<10 \mu \mathrm{g} \mathrm{L}{ }^{-1}$ for any herbicide runoff event. Thus, these years were excluded from Fig. 3. Although quantifiable herbicide runoff losses were observed in 2000, 2003, 2005, and 2006, no significant concentrations in runoff were observed $\geq 30 \mathrm{~d}$ after application. Surprisingly, a significant rainfall event occurred during 2002 within a week of application, but surface runoff concentrations never exceeded $5 \mu \mathrm{g} \mathrm{L}^{-1}$ for either herbicide for any runoff sample. Although the herbicides were applied in April in 2002 when surface soil tempera- tures were cold $\left(2^{\circ} \mathrm{C}\right)$, the reasons for the low runoff losses are not known. During the wettest year, 2001, runoff losses of atrazine exceeded $2.9 \%$ of that applied, whereas metolachlor runoff losses were 2.5\% (Table 1). Wauchope (1978) and Shipitalo and Owens (2006) also observed that herbicide runoff was the greatest when
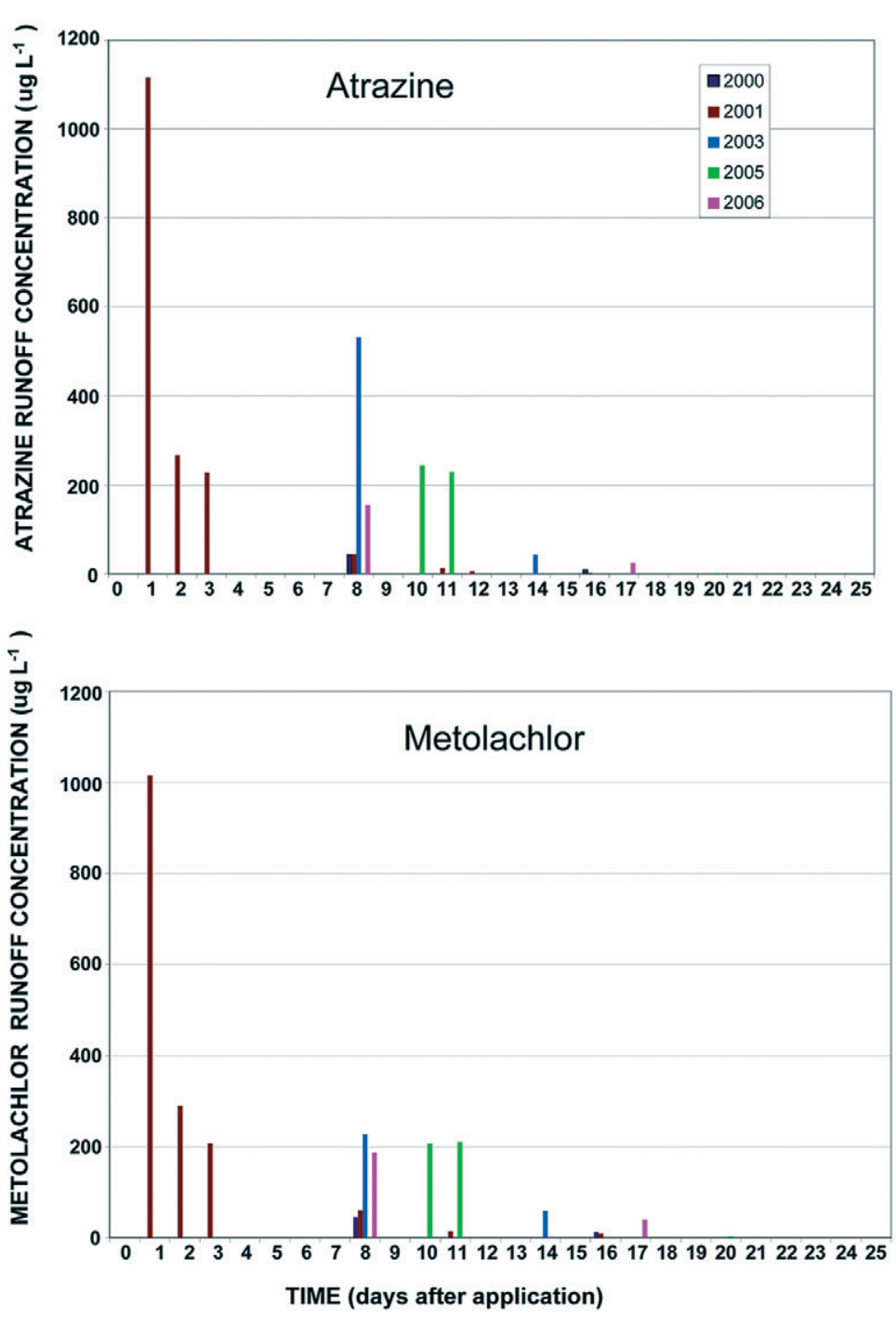

Fig. 3. Multiyear herbicide surface runoff. Runoff for years 2002, 2004, and 2007 are not shown, as the maximum herbicide runoff concentration for each of these $3 \mathrm{yr}$ was $<10 \mu \mathrm{g} \mathrm{L}^{-1}$. 
rain events occurred closest to application. However, due to the general lack of significant rainfall shortly after application on this site, herbicide runoff losses for 5 of the 8 yr were much less than $1 \%$ of that applied for either herbicide. No herbicide runoff was measured throughout all of 2007, likely because no water runoff occurred the first month after application (system was operating for the first month after application of 2007). Because this site has low organic matter content $(<3 \%)$, adsorption is expected to be minimal, increasing potential runoff (Caro, 1976; Spark and Swift, 2002). Additionally, when organic matter contents are low the clay mineral content becomes the dominant adsorption factor (Laird et al., 1992; Jenks et al., 1998), but this surface soil has a low clay content $<10 \%$.

Out of the $8 \mathrm{yr}$, only 5 generated significant herbicide runoff. An 8-yr average herbicide runoff concentration with days after application revealed an exponential decreasing function with coefficients of determination of 0.73 for atrazine and 0.78 for metolachlor. The 8-yr exponential fit also suggests that, in general, herbicide runoff concentrations $2 \mathrm{wk}$ after application would be $<8 \mu \mathrm{g} \mathrm{L}^{-1}$ for atrazine and $<12 \mu \mathrm{g} \mathrm{L} \mathrm{L}^{-1}$ for metolachlor. With the first meaningful precipitation events occurring well after 2 wk during 2004 and 2006, it is not surprising that these years generated negligible herbicide runoff. Furthermore, if each year is considered a replicate, significant differences between atrazine and metolachlor can be evaluated. Although atrazine and metolachlor have different water solubilities, there was no significant difference in herbicide runoff losses $(P>0.05)$. In general, the low herbicide runoff fluxes observed on this site are likely due to the low slope (generally $<2 \%$ ) because herbicide runoff generally increases with surface slope (Hall et al., 1983; Felsot et al., 1990). Wauchope (1978) reported that herbicide runoff from a $3 \%$ slope can be as high as $2 \%$ of that applied, whereas slopes of 10 to $15 \%$ may result in herbicide runoff losses $>5 \%$ of that applied. As a result, the low observed herbicide runoff values are probably due to little rainfall within the first $2 \mathrm{wk}$ after application, low surface slopes, and perhaps the sandy, well-drained characteristics of the research site.

\section{Herbicide Soil Surface Residues}

Herbicide soil recoveries in the top $5 \mathrm{~cm}$ for each sampling time varied over the $8 \mathrm{yr}$. The least amount of variability occurred at the time of application, where $\mathrm{T}_{0}$ atrazine mean recoveries for the $8 \mathrm{yr}$ were $76 \%$ of the anticipated application rate with a standard deviation of $37 \%$, whereas the 8 -yr mean metolachlor $\mathrm{T}_{0}$ recoveries were $72 \% \pm 35 \%$. Subsequent variability in spatial herbicide soil residue concentrations during the early morning (4:30 a.m. EST) sampling were also high for periods $\mathrm{T}_{1}, \mathrm{~T}_{2}, \mathrm{~T}_{3}, \mathrm{~T}_{4}$, and $\mathrm{T}_{5}$, where atrazine coefficients of variation were 67, 86, 63, 64 , and $57 \%$, respectively. Metolachlor soil residue spatial variability was similar to atrazine with coefficients of variation ranging from 45 to $60 \%$ for the same time periods.

Each year, atrazine and metolachlor average soil residue mass decreased exponentially with time. Although herbicide spatial variability is high in these soil samples, soil moisture appears to influence herbicide dissipation in the top $5 \mathrm{~cm}$ of soil (Fig. 4). Although 2001 and 2005 did not experience extreme moisture conditions, they are representative of moist and dry years, respectively (Table 3). For both atrazine and metolachlor, the moist year (2001) shows the largest loss occurring within the first $24 \mathrm{~h}$ after application. As a result, the enhanced recovery of both herbicides in dry soil is generally in response to reduced volatilization (Glotfelty et al., 1984, Prueger et al., 2005), although some runoff also occurred during 2001.

\section{Herbicide Volatilization}

Although many studies do not monitor nighttime herbicide vapor losses, the use of eddy covariance data allows nighttime losses to be accurately determined. However, herbicide volatilization was monitored for only $5 \mathrm{~d}$ and many of the cumulative volatilization curves in Fig. 5 through Fig. 7 indicate that volatilization losses would have likely continued past $5 \mathrm{~d}$, so these vapor flux losses are conservative estimates. Over the $8 \mathrm{yr}$, there is considerable variability in cumulative herbicide volatilization losses. For soil conditions typical of agronomic crop production (excluding 2003), cumulative metolachlor volatilization ranged from 6 to $>23 \%$ of that applied (Fig. 5), with a 7-yr average vapor loss of $9.5 \%$ of that applied and a CV of $80 \%$. Atrazine cumulative volatilization losses
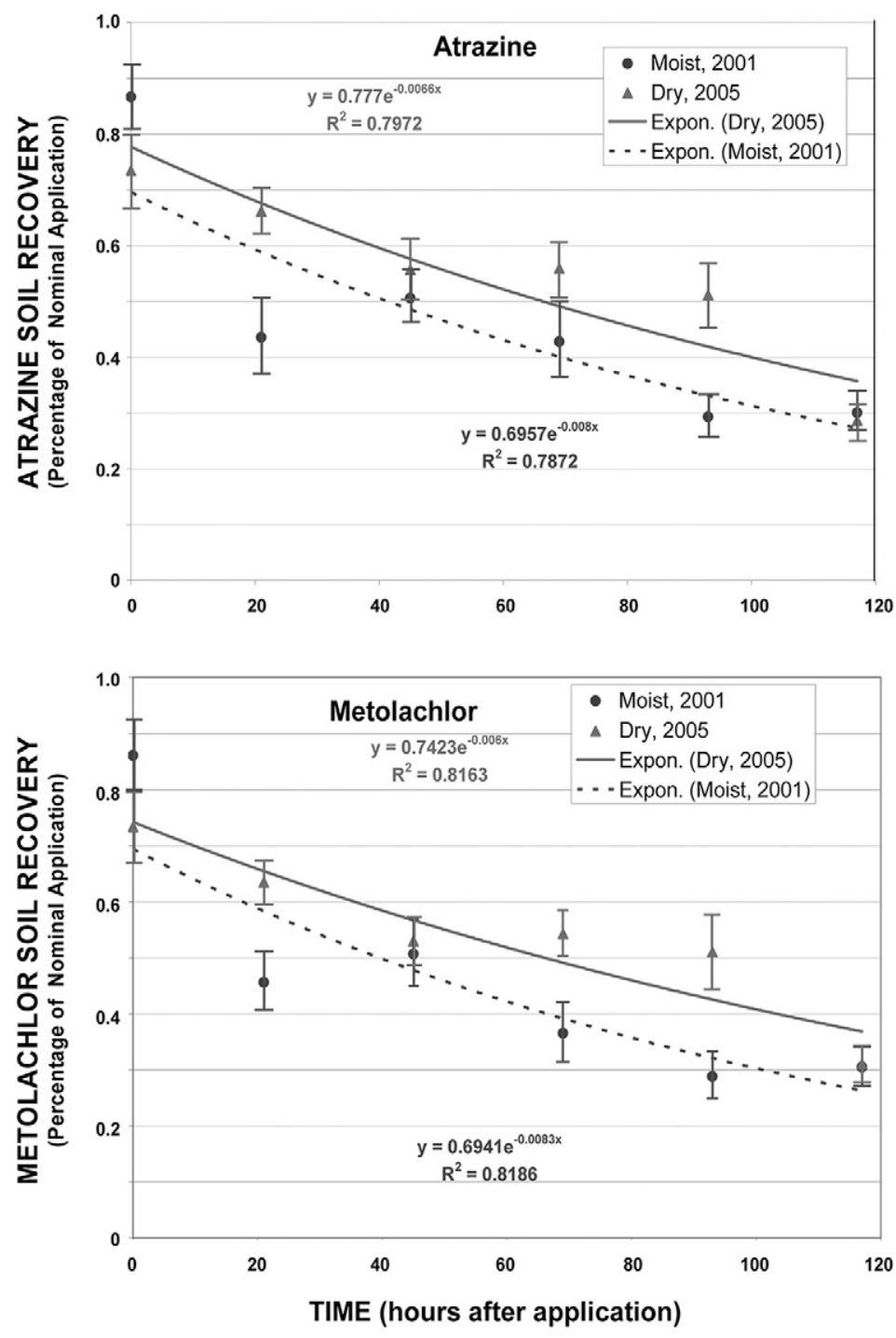

Fig. 4. Soil dissipation of metolachlor and atrazine as a function of time. Error bars denote \pm 1 standard error of the mean. 
were much lower, ranging from $<2$ to $6 \%$ of that applied (Fig. 6), with a $7-y r$ mean of $4 \%$ of that applied and a CV of $40 \%$. The magnitude of metolachlor volatilization corresponded well with surface soil moisture conditions, with 2001 having the greatest losses followed by 2004. For the driest soil conditions, 2006 and 2007, metolachlor volatilization was minimal, ranging from 6 to $7 \%$ of that applied. Cumulative atrazine volatilization losses were similar to metolachlor, with the highest vapor losses occurring during wet years (2004 and 2001). However, the lowest atrazine

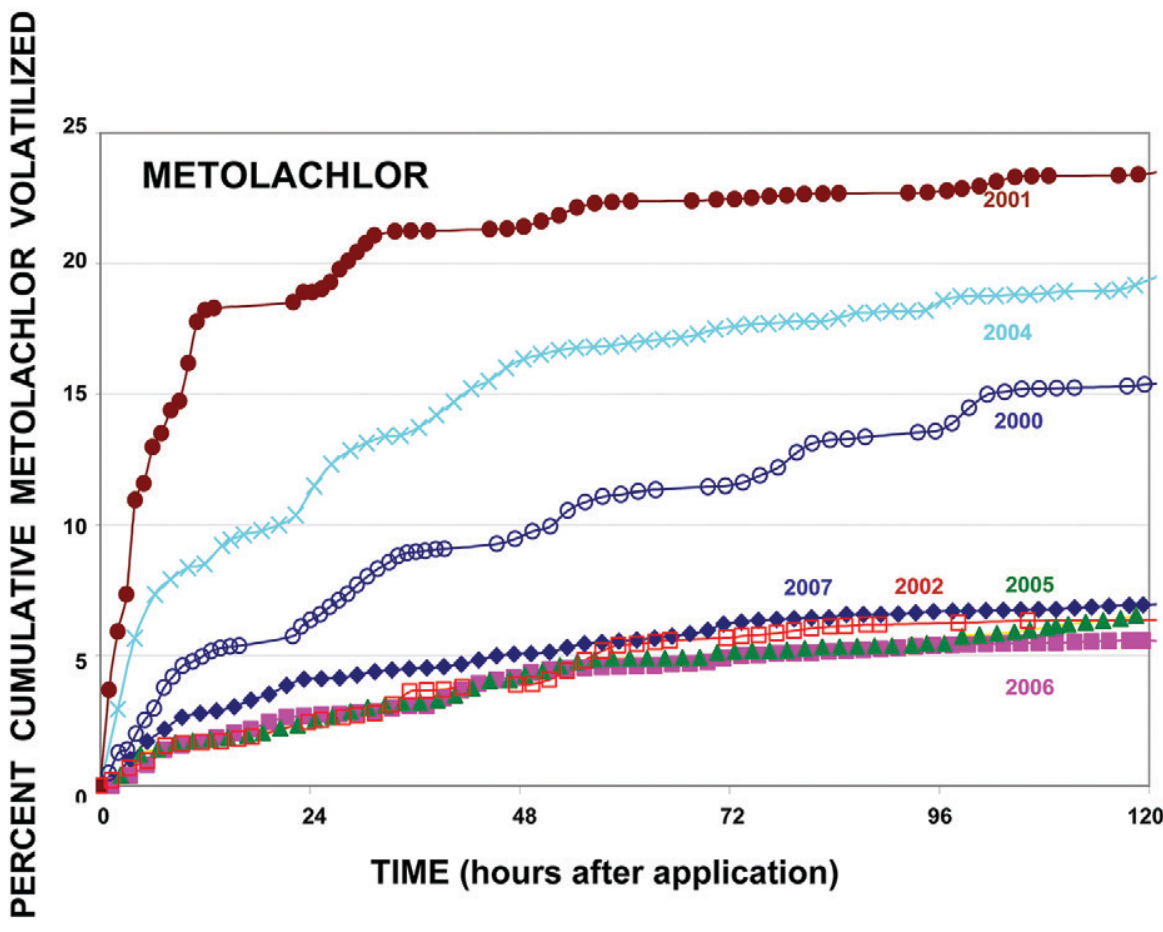

Fig. 5. Cumulative field-scale metolachlor volatilization losses (expressed as percent applied) as a function of time. Each year shown reveals atrazine volatilization losses from field conditions common to crop production activities.

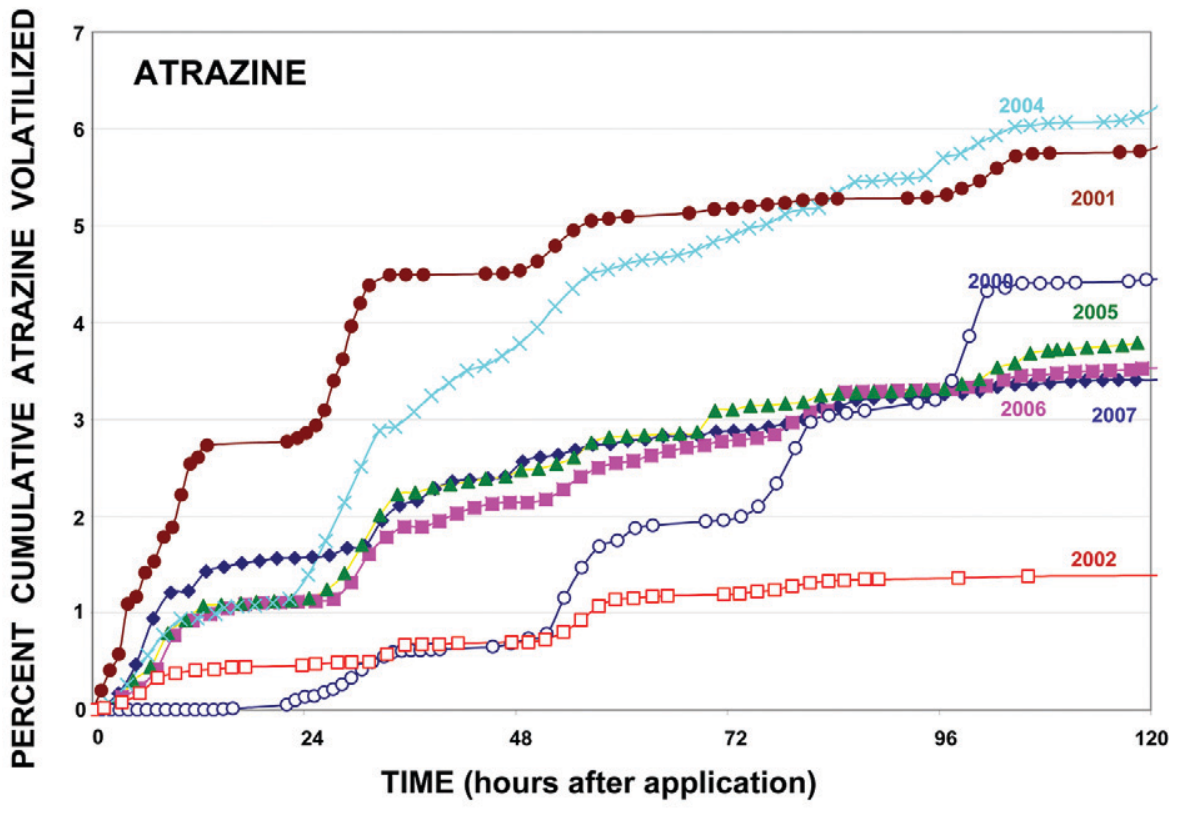

Fig. 6. Cumulative field-scale atrazine volatilization losses (expressed as percent applied) as a function of time after application. Each year shown reveals atrazine volatilization losses from field conditions common to crop production activities. losses occurred in 2002 when $<2 \%$ of that applied was lost after 5 d. The low atrazine losses in 2002 may have been due to low temperatures because spraying occurred in April of that year. For the driest years, 2006 and 2007, atrazine volatilization ranged from 3 to $4 \%$ of that applied. Using an exponential fit, the coefficients of determination for herbicide volatilization with the $\mathrm{T}_{0}$ surface soil moisture content were 0.80 and 0.94 for atrazine and metolachlor, respectively. As a result, for typical Maryland agronomic conditions, soil moisture has a critical impact on cumulative metolachlor vapor losses as they frequently exceed $15 \%$ of that applied. On the other hand, for identical soil and meteorological conditions, atrazine was less influenced by soil moisture.

Herbicide vapor losses were always much greater than those observed in surface runoff. Over the 8-yr period, metolachlor volatilization losses were 10 to $>150$ times larger than metolachlor runoff losses. Similarly, atrazine volatilization losses were 2 to $>130$ times larger than those observed in surface runoff. The greatest difference between volatilization and runoff losses occurred when runoff was negligible. Small rain events after herbicide application may not generate runoff but can significantly influence herbicide volatilization (Prueger et al., 2005; Gish et al., 2009). When each year is considered a replicate, herbicide volatilization losses were significantly greater than runoff losses $(P=0.007)$. Averaged over years, herbicide loss by volatilization dominated surface runoff by a factor of 9 for atrazine and 45 for metolachlor (Table 4). As a result, although rarely monitored, metolachlor and atrazine volatilization is a critical off-site transport mechanism for these two common herbicides.

The impact of surface soil moisture on herbicide volatilization may be primarily due to its influence on the herbicide vapor pressure. As the vapor pressure increases, the herbicide increasingly favors the vapor phase and is more readily volatilized. In the field, an "effective" herbicide vapor pressure is likely to be lower than the vapor pressure of the "pure" chemical due to interactions with the soil surface. For example, early studies detected a significant positive correlation between herbicide vapor pressure and herbicide volatilization (Farmer et al., 1972; Glotfelty et al., 1984). Later, it was observed that dry soil conditions favored soil adsorption, which reduced the vapor pressure of the herbicide and decreased herbicide volatilization (Spencer et al., 1969; Spencer and Cliath, 1974; Taylor and Spencer, 1990). Spencer and Cliath (1974) also measured the herbicide vapor 
pressures in soil at various soil water contents and demonstrated greater volatilization losses from wet soils than dry soils. And last, Glotfelty et al. (1984) and Gish et al. (2009) demonstrated that herbicide vapor losses increased more with increasing soil water content than with increasing organic matter.

During 2003, it rained at least weekly from early April through early July. Although most of the field site is well drained, the site was very wet in 2003-nearing saturation. Thus, special tractor tire modifications were required to avoid getting stuck during herbicide application. Additionally, during 2003, the herbicides were applied in the summer (14 July) when energy inputs were high. Although recent studies have shown an increase in herbicide volatilization with increasing surface soil moisture (Prueger et al., 2005), these results may be a worst-case scenario (Fig. 7). After $5 \mathrm{~d}$, volatilization was $62 \%$ of the applied metolachlor and $12 \%$ of the applied atrazine. Results from the 4:30 a.m. soil samples taken at $5 \mathrm{~d}$ after herbicide application also support the vapor flux data in that $65 \%$ of the applied metolachlor and $29 \%$ of the applied atrazine had dissipated from the top $5 \mathrm{~cm}$ of soil. As a result, although both herbicides are considered nonvolatile, $95 \%$ of the metolachlor lost after $5 \mathrm{~d}$ had done so through volatilization compared to $41 \%$ for atrazine.

Cumulative metolachlor and atrazine losses for all $8 \mathrm{yr}$ are shown in Table 5. Since 2003 was an atypical year, it was initially excluded from the calculated averages and estimates of variability. However, if included, the 8 -yr average atrazine vapor loss would be $5 \%$ of that applied with a CV of $62 \%$, whereas the 8 -yr metolachlor average would be $16 \%$ of that applied and exhibiting a CV of $125 \%$. Differences in mean losses and variability are likely due to metolachlor's greater water solubility and higher vapor pressure relative to atrazine (Table 2). As reported by Prueger et al. (2005), metolachlor volatilization was highly variable even though organic matter, soil texture, herbicide formulation, and agricultural management practices were unchanged throughout the $8 \mathrm{yr}$. Atrazine volatilization, on the other hand, was much less variable and appears to be influenced less by soil moisture, perhaps due to its lower water solubility.

Eddy covariance flux data allow nighttime vapor losses to be monitored, allowing a comparison of daytime and nighttime losses (Fig. 8 and 9). Average daytime metolachlor vapor losses (excluding 2003) were 9\% of that applied but exhibited a great deal of variability with a standard deviation of $7 \%$ and $\mathrm{CV}$ of $75 \%$. Nighttime metolachlor losses averaged $3 \%$ of that applied and had a standard deviation of only $1 \%$, which generates a CV of only $36 \%$. Nighttime metolachlor vapor losses were similar to daytime losses when the soils were dry $(2005,2006$, and 2007) but were much lower than daytime losses when soils were moist (2000, 2001, 2003, and 2004). However, even if the 8 yr were considered replicates, daytime metolachlor vapor losses were significantly larger than during the nighttime vapor losses $(P<$ 0.05 ). As a result, nighttime losses were fairly constant, but daytime losses were larger and more variable.

Atrazine daytime vapor losses averaged 3\% of that applied, whereas nighttime losses were $0.8 \%$. Variability for both daytime and nighttime atrazine losses were similar with a daytime standard deviation of $1.3 \%$ and nighttime standard deviation of $0.4 \%$, which generated CVs of $40 \%$ for daytime and $51 \%$ for nighttime. For both metolachlor and atrazine, the majority of the volatilization occurred during the day. However, unlike metolachlor, atrazine daytime volatilization losses were always much greater than nighttime losses, regardless of the soil moisture status. As a result, if the $8 \mathrm{yr}$ were considered as replicates, day-

Table 5. Yearly cumulative herbicide volatilization losses. $\dagger$

\begin{tabular}{lrrrrrrrr}
\hline \multirow{2}{*}{ Herbicide } & \multicolumn{7}{c}{ Yearly herbicide volatilization losses (\% of applied as a function) } \\
\cline { 2 - 9 } & $\mathbf{2 0 0 0}$ & $\mathbf{2 0 0 1}$ & $\mathbf{2 0 0 2}$ & $\mathbf{2 0 0 3}$ & $\mathbf{2 0 0 4}$ & $\mathbf{2 0 0 5}$ & $\mathbf{2 0 0 6}$ \\
\hline Metolachlor & 15.4 & 23.5 & 6.4 & 62.2 & 19.4 & 6.5 & 6.9 & $\mathbf{2 0 0 7}$ \\
Atrazine & 4.4 & 5.8 & 1.5 & 11.8 & 6.1 & 3.8 & 3.5 & 3.4 \\
\hline
\end{tabular}

† Cumulative losses are for only the first $5 \mathrm{~d}$ after application. 


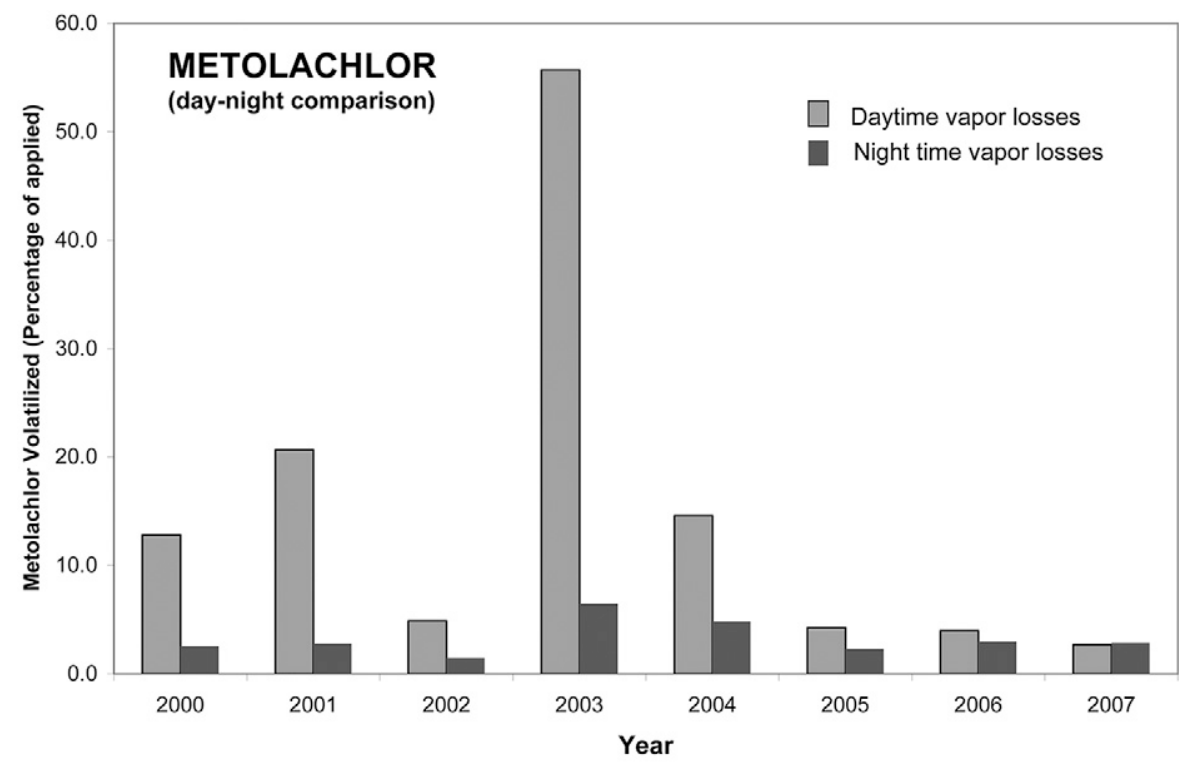

Fig. 8. Comparison of day and night metolachlor volatilization losses.

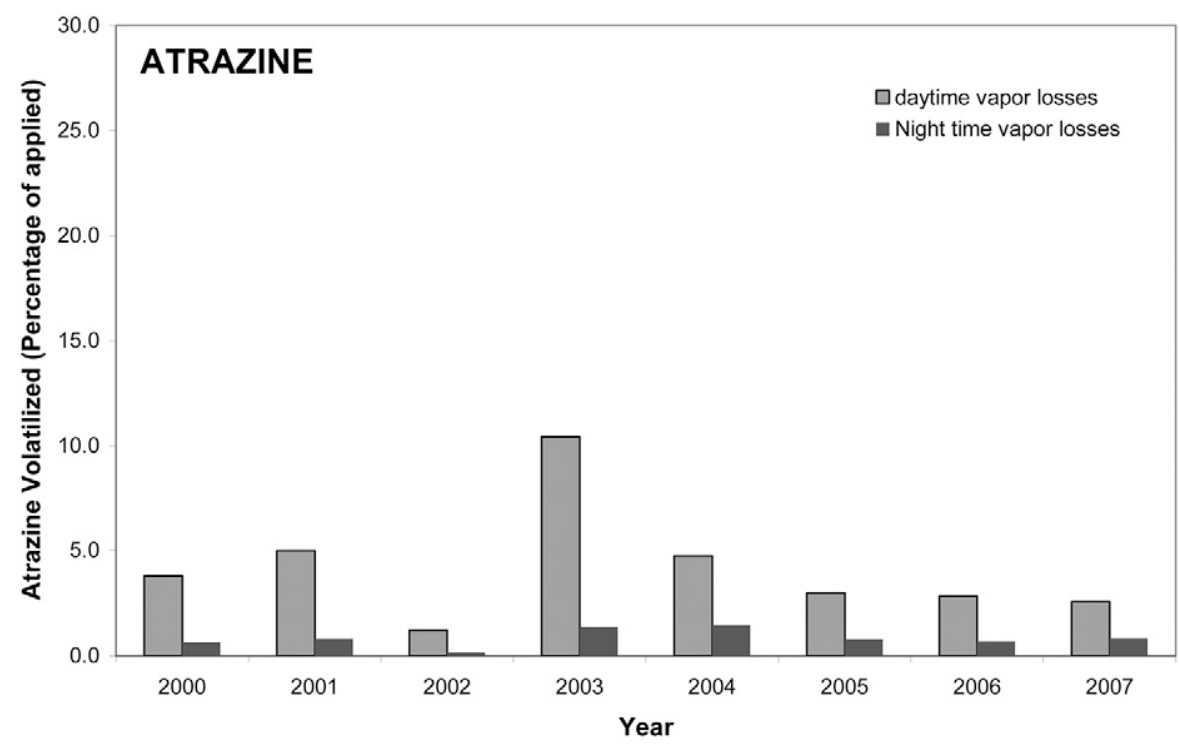

Fig. 9. Comparison of day and night atrazine volatilization losses.

time atrazine vapor losses were significantly larger than nighttime vapor losses $(P<0.03)$.

\section{Conclusion}

Metolachlor and atrazine volatilization and runoff was monitored and evaluated over an 8-yr period. Both atrazine and metolachlor vapor losses exhibited extensive year-to-year variability, even though agricultural management practices, herbicide formulation, crop, soil texture, and organic matter were unchanged. Metolachlor and atrazine vapor losses were both influenced by surface soil moisture, but metolachlor was affected to a greater degree. During the 8-yr investigation, a worst-case scenario occurred when herbicides were applied during high air temperatures and surface soil moisture conditions were near saturation. During this worst-case scenario, $63 \%$ of the applied metolachlor was lost through volatilization in only $5 \mathrm{~d}$, whereas, for these same extreme conditions, $12 \%$ of the applied atrazine was lost through volatilization. Excluding the worst-case scenario, average herbicide vapor losses were $9 \%$ for metolachlor and $4 \%$ for atrazine. When soils were moist, herbicide vapor losses increased dramatically, even though both of these herbicides have low vapor pressures. Daytime is the critical period governing herbicide volatilization. Nighttime losses of metolachlor and atrazine were fairly constant and atrazine nighttime losses were minimally affected by soil moisture.

During this study, atrazine and metolachlor volatilization was much greater than runoff losses. Runoff losses for both herbicides were generally much less than $1 \%$ of that applied. Only once in $8 \mathrm{yr}$, in 2001, did the atrazine surface runoff loss exceed $2.9 \%$ of that applied, whereas metolachlor runoff was $2.5 \%$ that same year. However, when herbicide runoff was significant, volatilization was also extensive because both processes are influenced by soil moisture. During 2001, precipitation occurred the day of application and $2.5 \%$ of the applied metolachlor was lost through surface runoff during the growing season. However, $23.5 \%$ of the applied metolachlor was lost through volatilization during the first $5 \mathrm{~d}$ after application. Additionally, herbicide volatilization losses were significantly larger than surface runoff $(P<0.007)$, and averaged over the two herbicides, loss by volatilization was about 25 times greater than surface runoff loss. This research confirms that vapor losses for some commonly used herbicides frequently exceed runoff losses. Furthermore, herbicide vapor losses on the same site and with the same management practices can vary significantly from year to year. This process will need to be fully understood if formulations and management practices are to be developed for reducing herbicide loads to the environment.

\section{Acknowledgments}

This paper is a contribution of the ARS network of long-term agricultural research sites.

\section{References}

Alegria, H.A., and T.J. Shaw. 1999. Rain deposition of atrazine and trifluralin in coastal waters of the South Atlantic Bight. Environ. Sci. Technol. 33:850-856.

Aspelin, A.L. 1994. Pesticide industrial sales and usage, 1992 and 1993 market estimates. Pub. 733-K-94-001. USEPA, Washington, DC.

Baker, J.L. 1980. Agricultural areas as nonpoint sources of pollution. p. 275-310. In M.R. Overcash and J.M. Davidson (ed.) Environmental impact of nonpoint source pollution. Ann Arbor Science Publication, Ann Arbor, MI.

Baldocchi, D., B.B. Hicks, and T.P. Meyers. 1988. Measuring biosphere-atmosphere exchanges of biologically related gases with micrometeorological methods. Ecology 69:1331-1340. 
Bidleman, T.F. 1988. Atmospheric process. Wet and dry deposition of organic compounds are controlled by their vapor-particle partitioning. Environ. Sci. Technol. 22:361-367.

Bidleman, T.F., and E.J. Christensen. 1979. Atmospheric removal processes for high molecular weight organochlorines. J. Geophys. Res. 84:7857-7862.

Burrows, H.D., M. Canle, J.A. Santaballa, and S. Steenken. 2002. Reaction pathways and mechanisms of photodegradation of pesticides. J. Photochem. Photobiol. B 67:71-108.

Capel, P.D., K.A. McCarthy, and J.E. Barbash. 2008. National, holistic, watershed-scale approach to understand the sources, transport, and fate of agricultural chemicals. J. Environ. Qual. 37:983-993.

Caro, J. 1976. Pesticides in agricultural runoff. p. 91-119. In B.A. Stewart (ed.) Control of water pollution from cropland. Vol. II. USEPA-600/275-026b. USEPA, Washington, DC.

Cousins, I.T., A.J. Beck, and K.C. Jones. 1999. A review of the processes involved in the exchange of semi-volatile organic compounds (SVOC) across the air-soil interface. Sci. Total Environ. 228:5-24.

Denmead, O.T., J.R. Simpson, and J.R. Freney. 1977. A direct field measurement of ammonia emission after injection of anhydrous ammonia. Soil Sci. Soc. Am. J. 41:1001-1004.

Domagalski, J.L., S. Ator, R. Coupe, K. McCarthy, D. Lampe, M. Sandstrom, and N. Baker. 2008. Comparative study of transport processes of nitrogen, phosphorus, and herbicides to streams in five agricultural basins, USA. J. Environ. Qual. 37:1158-1169.

Elliott, J.A., J.A. Cessna, W. Nicholaichuk, and L.C. Tollefson. 2000. Leaching rates and preferential flow of selected herbicides through tilled and untilled soil. J. Environ. Qual. 29:1650-1656.

Farmer, W.J., J.P. Martin, W.F. Spencer, and K. Igue. 1972. Volatility of organochlorine insecticides from soil: I. Effect of concentration, temperature, air flow rate, and vapor pressure. Soil Sci. Soc. Am. Proc. 36:443-447.

Felsot, A.S., J.K. Mitchell, and A.L. Kenimer. 1990. Assessment of management practices for reducing pesticide runoff from sloping cropland in Illinois. J. Environ. Qual. 19:539-545.

Gianessi, L.P., and M.B. Marcelli. 2000. Pesticide use in U.S. crop production: 1997. National Center for Food and Agricultural Policy, Washington, DC.

Gish, T.J., J.H. Prueger, W.P. Kustas, J.L. Hatfield, L.G. McKee, and A.L. Russ. 2009. Soil moisture and metolachlor volatilization observations over three years. J. Environ. Qual. 38:1785-1795.

Glotfelty, D.E., A.W. Taylor, B.J. Turner, and W.H. Zoller. 1984. Volatilization of surface applied pesticides from a fallow soil. J. Agric. Food Chem. 32:638-643.

Glotfelty, D.E., and C.J. Schomburg. 1989. Volatilization of pesticides from soil. p. 181-207. In B.L. Sawhey and K. Brown (ed.) Reactions and movement of organic chemicals in soils. Special Publ. 22. SSSA, Madison, WI.

Goodrich, D.C., T.J. Schmugge, T.J. Jackson, C.L. Unkrich, T.O. Keefer, R. Parry, L.B. Bach, and S.A. Amer. 1994. Runoff simulation sensitivity to remotelysensed initial soil water content. Water Resour. Res. 30:1393-1405.

Grover, R., A.E. Smith, S.R. Shewchuk, A.J. Cessna, and J.H. Hunter. 1988. Fate of trifluralin and triallate applied as a mixture to a wheat field. J. Environ. Qual. 17:543-550.

Hall, J.K., N.L. Hartwig, and L.D. Hoffman. 1983. Application mode and alternate cropping effects on atrazine losses from a hillside. J. Environ. Qual. 12:336-340.

Haith, D.A., and F.S. Rossi. 2003. Risk assessment of pesticides from turf. J. Environ. Qual. 32:447-455.

Jarvis, N.J. 2002. Macropore and preferential flow. p. 1005-1013. In J. Plimmer (ed.) The encyclopedia of agrochemicals. Vol. 3. John Wiley \& Sons, Hoboken, NJ.

Jenks, B.M., F.W. Roeth, A.R. Martin, and D.L. McCallister. 1998. Influence of surface and subsurface soil properties on atrazine sorption and degradation. Weed Sci. 46:132-138.

Jury, W.A., W.F. Spencer, and W.J. Farmer. 1983. Behavior assessment model for trace organics in soil: 1. Model description. J. Environ. Qual. 12:558-564.

Kodesova, R., M. Kocarek, V. Kodes, J. Simunek, and J. Zozak. 2008. Impact of soil micromorphological features on water flow and herbicide transport in soils. Vadose Zone J. 7:798-809.

Koplin, D.W., J.E. Barbash, and R.J. Gilliom. 1998. Occurrence of pesticides in shallow groundwater of the United States: Initial results from the National Water-Quality Assessment Program. Environ. Sci. Technol. 32:558-566.

Kuang, Z., L.L. McConnell, A. Torrents, D. Meritt, and S. Tobash. 2003. Atmospheric deposition of pesticides to an agricultural watershed of the Chesapeake Bay. J. Environ. Qual. 32:1611-1622.

LaFleur, K.S., W.R. McCaskil, and D.S. Adams. 1975. Movement of prometryne through Congaree soil into groundwater. J. Environ. Qual. 4:132-133.

Laird, D.A., E. Barriuso, R.H. Dowdy, and W.C. Koskinen. 1992. Adsorption of atrazine on smectites. Soil Sci. Soc. Am. J. 56:62-67.

Lyman, W.J., W.F. Reehl, and D.H. Rosenblatt. 1990. Handbook of chemical property estimation methods. Am. Chem. Soc., Washington, DC.

Majewski, M.S., and P.D. Capel. 1995. Pesticides in the atmosphere, distribution, trends, and governing factors. Ann Arbor Press, Chelsea, MI.

Malone, R.W., M.J. Shipitalo, and D.W. Meek. 2004a. Relationship between herbicide concentration in percolate, percolate breakthrough time, and the number of active macropores. Trans. ASAE 47:1453-1456.

Malone, R.W., M.J. Shipitalo, R.D. Wauchope, and N.R. Sumner. 2004b. Residual and contact herbicide transport through field lysimeters via preferential flow. J. Environ. Qual. 33:2141-2148.

McConnell, L.L., J.S. LeNoir, S. Datta, and J.N. Seiber. 1998. Wet deposition of current-use pesticides in the Sierra Nevada mountain range, California, USA. Environ. Toxicol. Chem. 17:1908-1916.

Muir, D.C., and B.E. Baker. 1976. Detection of triazine herbicide and their degradation products in tile-drain water from fields under intensive corn (maize) production. J. Agric. Food Chem. 24:122-125.

Ng, H.Y.F., J.D. Gaynor, C.S. Tan, and C.F. Drury. 1995. Dissipation and loss of atrazine and metolachlor in surface and subsurface drain water: A case study. Water Res. 29:2309-2317.

Parmele, L.H., E.R. Lemon, and A.W. Taylor. 1972. Micrometeorological measurement of pesticide vapor flux from bare soil and corn under field conditions. Water Air Soil Pollut. 1:433-451.

Prueger, J.H., T.J. Gish, L.L. McConnell, L.G. McKee, J.L. Hatfield, and W.P. Kustas. 2005. Solar radiation, relative humidity, and soil water effects on metolachlor volatilization. Environ. Sci. Technol. 39:5219-5226.

Prueger, J.H., J.L. Hatfield, and T.J. Sauer. 1999. Field-scale metolachlor volatilization flux estimates from broadcast and banded application methods in central Iowa. J. Environ. Qual. 28:75-81.

Rice, C.P., C.B. Nochetto, and P. Zara. 2002. Volatilization of trifluralin, atrazine, metolachlor, chlorpyrifos, $\alpha$-endosulfan, and $\beta$-endosulfan from freshly tilled soil. J. Agric. Food Chem. 50:4009-4017.

Spark, K.M., and R.S. Swift. 2002. Effect of soil composition and dissolved organic matter on pesticide sorption. Sci. Total Environ. 298:147-161.

Shipitalo, M.J., and L.B. Owens. 2006. Tillage system, application rate, and extreme event effects on herbicide losses in surface runoff. J. Environ. Qual. 35:2186-2194.

Spencer, W.F., M.M. Cliath, and W.J. Farmer. 1969. Vapor density of soil-applied dieldrin as related to soil-water content, temperature, and dieldrin concentration. Soil Sci. Soc. Am. Proc. 33:509-511.

Spencer, W.F., and M.M. Cliath. 1974. Factor affecting vapor loss of trifluralin from soil. J. Agric. Food Chem. 20:987-991.

Symons, P.E.K. 1977. Dispersal and toxicology of the insecticide fenitrothian; predicting hazards of forest spraying. Residue Rev. 68:1-36.

Taylor, A.W. 1995. The volatilization of pesticide residues. p. 257-306. In T.R. Roberts and P.C. Kearney (ed.) Environmental Behavior of Agrochemicals. Vol. 9. John Wiley \& Sons, Hoboken, NJ.

Taylor, A.W., and W.F. Spencer. 1990. Volatilization and vapor transport processes. p. 213-269. In H.H. Cheng (ed.) Pesticides in the soil environment: Processes, impacts, and modeling. SSSA, Madison, WI.

Thurman, E.M., and A.E. Cromwell. 2000. Atmospheric transport, deposition, and fate of triazine herbicides and their metabolites in pristine areas at Isle Royale National Park. Environ. Sci. Technol. 34:3079-3085.

Tsal, W., and Y. Cohen. 1991. Dynamic partitioning of semivolatile organics in gas/particle/rain phases during rain scavenging. Environ. Sci. Technol. 25:2012-2023.

USGS. 2002. Pesticide National Synthesis Project. Available at http://water. usgs.gov/nawqa/pnsp/usage/maps/compound_listing.php?year=02 (verified 18 Aug. 2010).

USEPA. 2008. Drinking water contaminants. Available at http://www.epa. gov/safewater/contaminants/index.html (verified 18 Aug. 2010). EPA 816-F-03-016, June 2003.

Verma, S.B. 1990. Micrometeorological methods for measuring surface fluxes of mass and energy. Remote Sens. Rev. 5:99-115.

Wauchope, R.D. 1978. The pesticide content of surface water draining from agricultural fields: A review. J. Environ. Qual. 7:459-472.

Wienhold, B.J., and T.J. Gish. 1994. Effect of formulation and tillage practice on volatilization of atrazine and alachlor. J. Environ. Qual. 23:292-298.

Wilson, J.D., G.W. Thurtell, G. Kidd, and E. Beauchamp. 1982. Estimation of the rate of gaseous mass transfer from a surface source plot to the atmosphere. Atmos. Environ. 16:1861-1867. 